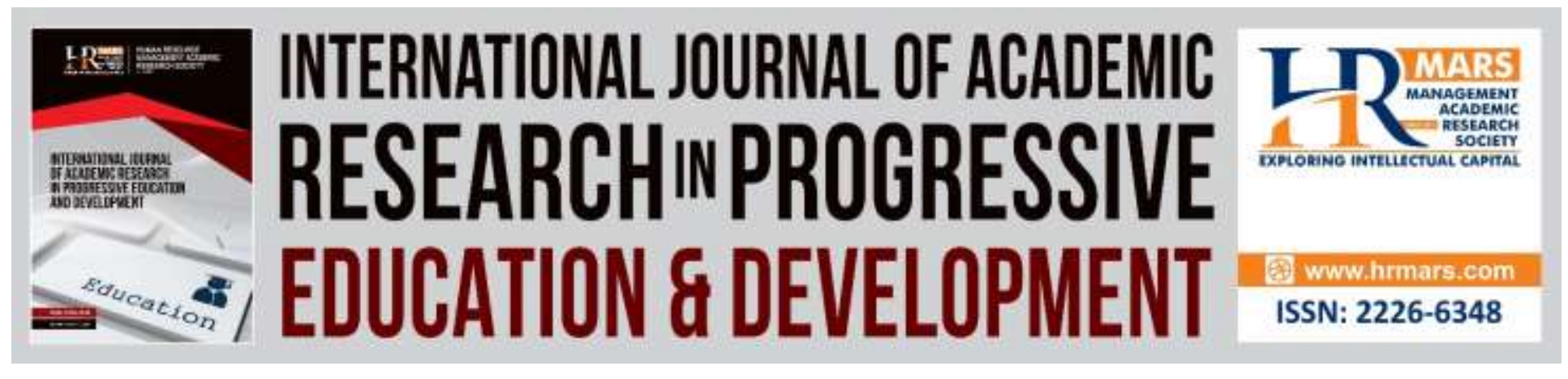

\title{
Conceptual Framework for Integration of Tauhidic Elements for Environmental Conservation (TEFEC): A Review
}

Norshariani Abd Rahman, Fatin Nur Marhamah Zabidi, Mohd Yusof Othman, Lilia Halim, Zanaton Iksan \& Wan Nasyrudin Wan Abdullah

To Link this Article: http://dx.doi.org/10.6007/IJARPED/v8-i3/6265

DOI: 10.6007/IJARPED/v8-i3/6265

Received: 15 May 2019, Revised: 16 June 2019, Accepted: 10 July 2019

Published Online: 29 August 2019

In-Text Citation: (Rahman et al., 2019)

To Cite this Article: Rahman, N. A., Zabidi, F. N. M., Othman, M. Y., Halim, L., Iksan, Z., \& Abdullah, W. N. W. (2019). Conceptual Framework for Integration of Tauhidic Elements for Environmental Conservation (TEfEC): A Review. International Journal of Academic Research in Progressive Education and Development, 8(3), 7083.

Copyright: (c) 2019 The Author(s)

Published by Human Resource Management Academic Research Society (www.hrmars.com)

This article is published under the Creative Commons Attribution (CC BY 4.0) license. Anyone may reproduce, distribute, translate and create derivative works of this article (for both commercial and non-commercial purposes), subject to full attribution to the original publication and authors. The full terms of this license may be seen at: http://creativecommons.org/licences/by/4.0/legalcode

Vol. 8(3) 2019, Pg. 70 - 83

http://hrmars.com/index.php/pages/detail/IJARPED

JOURNAL HOMEPAGE

Full Terms \& Conditions of access and use can be found at http://hrmars.com/index.php/pages/detail/publication-ethics 


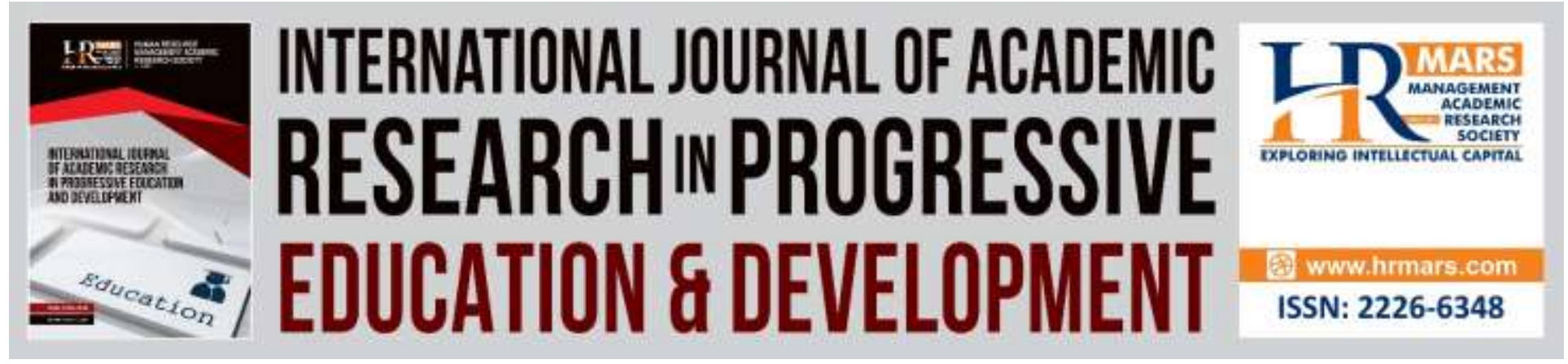

\title{
Conceptual Framework for Integration of Tauhidic Elements for Environmental Conservation (TEFEC): A Review
}

\author{
${ }^{1}$ Norshariani Abd Rahman, ${ }^{2}$ Fatin Nur Marhamah Zabidi, ${ }^{1}$ Mohd \\ Yusof Othman, ${ }^{1,2}$ Lilia Halim, ${ }^{2}$ Zanaton Iksan \& ${ }^{1,3}$ Wan Nasyrudin \\ Wan Abdullah \\ ${ }^{1}$ Institute of Islam Hadhari, Universiti Kebangsaan Malaysia, 43600 Bangi, MALAYSIA \\ ${ }^{2}$ Faculty of Education, Universiti Kebangsaan Malaysia, 43600 Bangi, MALAYSIA \\ ${ }^{3}$ Faculty of Islamic Studies, Universiti Kebangsaan Malaysia, 43600 Bangi, MALAYSIA
}

Email: norshariani@ukm.edu.my

\begin{abstract}
Islam provides solutions to various environmental problems and Islamic principles are essential for environmental conservation. Therefore, the integration of tauhidic elements is required in providing a more comprehensive solution for environmental conservation. However, in providing guidance for the implementation of the integration of tauhidic elements for environmental conservation (TEFEC), a conceptual framework for TEFEC needs to be developed. Thus, the aim of this study is to develop a conceptual framework for TEFEC based on literature review analysis and synthesis. The literature review was based on articles taken from Ebscohost Discovery through the database of PTSL library, UKM, Researchgate and Google Scholar. Books related to environmental education from the Islamic perspective, as well as related thesis and proceedings were also considered. The papers analyzed were those published from 2010 to 2018, encompassing a period of 8 years. The findings show that in order to integrate TEFEC, three relationships need to be maintained in the environmental conservation efforts i.e., relationship with the creator (Allah), with fellow human beings and the environment. Integration of TEFEC can also be applied through three approaches i.e., through teachings from the al-Quran, the hadith and Islamic values that are related to environmental conservation. Investigation of the content of the al-Quran verses, the hadiths or the as-Sunnah and the Islamic values can enhance environmental value, environmental knowledge, and attitude. Additionally, environmental problem solving skills are also needed. The final goal of the conceptual framework for TEFEC is to create responsible behavior toward the environment. The conceptual framework for integration
\end{abstract}


of TEFEC can be applied in environmental education to create a society that is responsible for conservation of the environment based on Islam.

Keywords: Tauhidic Elements, Environmental Education, Environmental Conservation, Islamic Values

\section{Introduction}

Humans have been appointed as khalifah who are entrusted to maintain the harmony of nature. The lack of appreciation of the role as khalifah on this earth has resulted in escalating environmental crises. This situation clearly shows that the damage on the environment is due to the internal problems of human beings (Kamidin \& Roslan, 2014). Human beings must be aware of their responsibility on this earth as we are not the owners of nature but only its temporary guardians (Rusdi, 2010; Hidayat 2015; Mănoiu et al., 2016). Moreover, Islamic values related to environmental protection are emphasized in the al-Quran, for example the concepts of moderation, gratefulness, appreciation of the environment, and avoiding environmental damage (Mangunjaya, 2011; Yaacob et al., 2017). However, the behavior of being responsible for environmental care is also eroding as a result of the lack of appreciation of Islamic values related to environmental protection based on the Quran and as-Sunnah (Abdul-Matin, 2010; Rusdi, 2010). Additionally, it could be argued that the segregation of the human value in the education system has also led to the ever-increasing cases of environmental damage (Lewis, 2007). Hence, it is crucial for society to understand the role of human beings as khalifah on this earth.

Environmental education plays an important role in tackling environmental problems. In recent years, there has been an increasing interest in searching for a holistic approach in finding solutions to environmental problems through education. In Malaysia, environmental education has been conducted across the curriculum in schools (Ministry of Education, 1998) and beginning in 2019, the Ministry of Education will be working toward making environmental education as a single subject (Rahman, 2018). Since environmental education is conducted across the curricula, there is less concern about the effectiveness of environmental education; additionally, environmental education carried out in schools faces a lot of constraints even until now. Among these constraints are the lack of understanding of the concept of environmental education, logistical limitations (i.e. large class size, risk of bringing students out, compact curriculum, and time constraints), as well as teachers' competencies and teachers' commitment to environmental education (Ham \& Sewing, 1988; Ahmad, 2009; Rahman, 2018). The constraints in applying environmental education in schools will continue to occur if no effort is taken to find solutions. Furthermore, the goal of environmental education has not been fully achieved because of the lack of emphasis on environmental values, decision-making skills and environmental problem solving skills among students (Rahman, 2018).

Moreover, even though education for sustainability has existed in schools, tauhidic elements for environmental conservation has not been emphasized for Muslim students in schools. The problem faced is that Muslim students are often taught to memorize the al-Qur'an without understanding how to apply the values related to environmental care mentioned in the 
al-Qur'an in environmental conservation activities. Thus, guidance on how to tadabbur the alQur'an in the context of environmental conservation needs to be investigated.

One of the learning strategies to enhance environmental care behavior systematically is by developing and using modules of environmental education in schools. Based on reviews of relevant literature, several attempts have been made by researchers and government agencies to develop environmental education modules (Ministry of Education, 1998; Ramli, 2003; Kamidin \& Roslan, 2014; Savita et al., 2017). However, the module of environmental education which integrated the concept of tauhid was poorly developed. A tauhidic environmental education module has been developed in Malaysia. However, the module focused on fieldwork activities and activities outside of the classroom (Iksan et al., 2015). Clearly, the implementation of such a module will involve high costs and logistical issues in terms of having to take students out of the classroom or school. Taking these into consideration, the application of environmental education is more appropriate if they are carried out in the school setting as this would be able to address the issues of cost and logistics involved in taking students out of the school setting.

Therefore, the concept, the characteristics and the approaches in integrating tauhidic elements for environmental conservation (TEFEC) should be studied to ensure that environmental education can be carried out effectively in schools. Derived from the literature review, TEfEC can be defined as an education where moral values toward environmental care behavior is infused based on the al-Quran, the hadith and the teachings of Islamic values to create awareness of the environment by maintaining the relationship with Allah, fellow human beings and the environment, and demonstrating responsible environmental behavior toward the environment (Djainudin \& Sirait, 2016). Accordingly, a conceptual framework for tauhidic elements for environmental conservation based on the concept of TEFEC needs to be developed. The conceptual framework may act as a guide to help teachers infuse tauhidic elements in environmental education as a complementary approach for Muslim students.

\section{Literature Review}

Many of the previous studies were more concerned about delineating the contents that need to be included in environmental education. However, the approach used did not elaborate in detail the manner in which the integration of tauhidic elements for environmental conservation was to be implemented. Additionally, the kinds of skills that should be taught or imparted to the students were not emphasized as well. Yaacob et al. (2017) found that the transformation of such behavior of Muslims in Malaysia toward environmental sustainability is not based on Islamic values but more in terms of economy, social, education level and the enforcement of law and regulations. This suggests that Islamic teachings on the environment which stem from al-Quran verses and the as-Sunnah are not an integral part of a Muslim's daily routine. Thus, the way in which TEfEC could be effectively infused in environmental education in schools should be examined.

Previous studies on TEfEC involved the analysis of the content of the al-Quran and the mixed method approach where both the qualitative and quantitative approaches were employed 
(Akhter, Iqbal \& Khalid, 2010; Iksan et al., 2015; Mănoiu et al., 2016; Rahim, 2017). Among the techniques used were interviews, questionnaires and observations. The method is good for obtaining output regarding the implementation of TEfEC. However, it would be better if experts on environmental education, tauhidic science education and environmental educator are engaged and asked to cooperate and give their opinion and input on suitable or effective approaches in applying TEfEC and in planning the content of TEfEC so that a more comprehensive result can be obtained. Thus, it is suggested that the TEfEC module to be developed for teaching and learning of environmental education in this present study takes into consideration opinions of various experts in this area so that effective approaches can be developed for use with Muslim school students.

Research findings related to informal infusion of environmental education at home as studied by Mustam and Daniel (2018) can be considered for infusion in the school setting through activities involving verbal communication, action or behavior and instilling of moral values. This activity approach can be implemented through environmental awareness programs and creation of the 'greendeen' of environmental practices in the school environment. These activities act as a reinforcement to develop Islamic ethical behavior toward the environment among Muslim students. Additionally, in several studies conducted on Islamic environmental education in Islamic Boarding Schools in Indonesia, various approaches were implemented including teaching, modelling, coercion, conducting participatory activities (such as cleaning Friday, arrangement of the garden and the surrounding environment, creation of green open space), and building collective awareness about the importance of environmental management through daily activities (Efendi et al., 2017; Albab 2018; Fua et al. 2018).

Sakka et al. (2016) developed an environmental education learning model for vocational high schools in Palopo. The model known as Plan, Observation, Revision, Evaluation and Value Environmental Education (POREV-EE) focused on online computer-based learning related to environmental issues. The results show that the developed model can improve students' knowledge and affective aspects. The study highlighted that the benefits of using the POREV-EE model included students learn more effectively individually, teaching materials are easily remembered because the materials are presented in the form of images of environmental problems, students do not get bored, students are stimulated to learn through interactions with computers, students become more creative, and students can be directly evaluated by the computer. Taking these benefits into consideration and in keeping with the present-day technological advancement, this approach can be adapted and infused inthe TEfEC module for environmental education.

Fua et al. (2018) and Mustam and Daniel (2018) investigated the approach of creating environmental care practices in school through participatory activities such as cleaning, garden arrangement and arrangement of the surrounding environment, creation of green open space, and building collective awareness on the importance of environmental management through daily activities. However, the manner or the ways in which Islamic values are to be infused so as to enhance participants' appreciation and internalization of these values were not clearly 
demonstrated in the studies. In addition, the teaching techniques used in the formal classroom as investigated by Mustam and Daniel (2018) did not include al-Quran verses and the hadith as an approach to tadabbur the al-Quran in relation to environmental conservation.

In contrast, Iksan et al. (2015) in their study did implement the approach of tadabbur alQuran while carrying out jungle trekking and tazkirah while doing fieldwork. This approach is a good example of how tauhidic elements can be integrated for environmental conservation. However, if the approach by Iksan et al. (2015) was to be implemented in the school environment, it would incur problems of cost, logistics, and safety for the school students as they need to be taken out of the school setting. A solution would be to adapt the approach by Iksan et al. (2015) to suit the school setting as implemented by Hamzah and Iksan (2017) in their study which investigated a lesson on water cycle that integrated verses in the al-Qur'an related to the topic. In the activity, the participants were asked to search for verses in the al-Quran that are related to water cycle. Hence, a strength of the activity is that it helps to enhance the relationship between the aqli and naqli knowledge among the participants. However, the activity did not focus on student's holistic skills in terms of demonstrating responsible environmental behavior related to the environmental issues learned.

The literature review has highlighted the problems and the research gap in the area of environmental education in Malaysia, specifically in relation to TEfEC and integration of Islamic values in environmental education. Hence, there is a need to conduct a comprehensive literature review to identify the concept of TEfEC and develop a conceptual framework for the integration of tauhidic elements for environmental conservation (TEfEC).

\section{Research Methodology}

The method used in this study involved analyzing and synthesizing the literature review related to the concept of TEfEC. The papers selected for analysis were from Ebscohost Discovery which was accessed through the database of UKM's PTSL library, in addition to papers searched through Researchgate and Google Scholar. Books, thesis and proceedings related to environmental education from the Islamic perspective were also taken into consideration. The time range for the analyzed papers was within 8 years (between 2010-2018). Papers that met the criteria pertaining to the concept of TEFEC were accessed and then analyzed. Data were extracted from the abstracts first and then followed by the full papers where themes and sub themes related to the concept of TEfEC were identified. Qualitative analysis was carried out using content analysis to identify themes related to the concept of TEfEC. The resulting sub themes were then organized into appropriate themes. Finally, the concept of TEfEC was transformed into a conceptual framework for integration of TEfEC in environmental education.

\section{Research Findings and Discussion}

The Concept of Tauhidic Elements for Environmental Conservation (TEfEC)

Muslims belief everything is created by God and human beings are a very special creature in the universe. There are three fundamental principles of Islam i.e. tauhid, khalafah and akhirah. Tauhid is one of the fundamental terms of Islamic teaching which means the conviction that "there is no God but Allah" (Akhter, Iqbal \& Khalid, 2010; Tamuri, 2015, Salehudin, Nusaibah \& 
Iksan, 2017) and is part of a Muslim's belief (Djainudin \& Sirait, 2016). In Islam, tauhid is not limited to the aspect of divineness or metaphysics but involves the aspect of universal principle or rule that will guide all human activities so that they obey or conform to the will of Allah (Akhter, Iqbal \& Khalid, 2010; Tamuri, 2015). Meanwhile, the khalafah is responsible for obedience to God's ruleand to protect His belongings on earth including the environment (Akhter, lqbal \& Khalid, 2010). Another significant notion of Islam is known as akhirah, i.e. 'the day of judgement' in which a khalifah would be accountable to God for all of his or her actions (Akhter, lqbal \& Khalid, 2010)

The concept of tauhid is the core or essence in the education system. There is an integrated relationship among tauhid, knowledge and action because all these aspects complement each other and do not only remain as an individual's intentions or thoughts but should be interpreted or implemented through real actions (Tamuri, 2015). In essence, the strong belief in Allah and true understanding of the tauhidic concept should refrain or prevent any Muslim from committing sin or evil because he or she realizes the punishment and consequences from Allah in the Hereafter (Tamuri, 2015). This belief also needs to be upheld in the context of environmental management. Environmental destruction is a result of human neglect of Islamic teaching as well as the problem of understanding of tauhid (Akhter, Iqbal \& Khalid, 2010; Tamuri, 2015). Hence, the understanding of the concept of tauhid for environmental conservation is important in controlling environmental destruction from continuing to happen.

According to Djainudin and Sirait (2016), the concept of tauhidic environmental education is a result of ethics toward the environment, the highest appreciation of nature, respect toward the interconnectedness of each component of the environment and the aspect of life, the confession of the Oneness of the Creator and the brotherhood of all beings. This shows that morality should be the basis of human behavior. Thus, tauhid can be said as the main source of values and ethics in the theology of environmental management (Djainudin \& Sirait, 2016).

Tauhidic elements for environmental conservation (TEFEC) can be implemented through the integration of tauhidic values and environmental values as well as through making the environment as the medium and source of applying tauhidic values such as learning outside the classroom, field work, and environmental research (Djainudin \& Sirait, 2016). The implementation of TEfEC is also in keeping with the views of Albab (2018) which emphasizes on the cultivation of students' environmental practices, demonstrating good example or practices, and enculturing feelings of love and concern toward the environment. In addition, Muslims are also required to take heed and lessons from the natural disasters that happen because of maladministration and flaws in environmental management. The way we relate to the environment also shows how our relationship is with Allah, with fellow human beings and with other creatures on this Earth.

Therefore, on the whole, it can be concluded that tauhidic elements for environmental conservation (TEfEC) is education that applies akhlak (moral) in environmental conservation through the inception of values cultivation, knowledge and attitude based on the al-Quran, the 
hadith, as well as Islamic teachings in order to create environmental awareness by taking care the relationship with Allah, with fellow human beings, and the environment and translated into responsible behavior toward the environment.

\section{Conceptual Framework of Integrating Tauhidic Elements for Environmental Conservation (TEfEC)}

Based on the literature review on concepts, characteristics, and integrated approach of TEfEC, a conceptual framework of TEfEC has been developed. This conceptual framework is triangular in form which begins with God at the highest peak while human beings (as the khalifah) and the environment are placed in the horizontal lines at the base of the triangle. This triangular form reflects the relationship between Allah, human beings and the environment (Iksan, Saper \& Rashed, 2016). The first source of reference is the al-Quran, followed by the hadith or as-Sunnah and Islamic values related to environmental education. The al-Quran is the primary source of knowledge for Muslims (Akhter, Iqbal \& Khalid, 2010). The process of taking the al-Quran as a reference involves identifying, listing, sorting and grouping (Haddad, 2006).Through the activity of tadabbur al-Quran, the greatness of God can be felt, feelings of gratitude can be evoked, and the warnings of Allah as contained in the al-Quran can be learned (Iksan et al. 2015). In the Qur'an, it is estimated that 750 verses (from 6236 verses) refer to various aspects of the environment as well as the relationship between humans and the environment (Mănoiu et al., 2016). The al-Quran has concluded that the damage to the environment is due to extreme human actions of immorality and disobedience, the arrogant attitude of human beings on earth, human beings following their desires and turning away from the law of the sunnatullah and the provisions of nature and the disbelievers who deny the blessings of Allah SWT (Abdul-Matin, 2010; Rusdi, 2010; Rahman, 2016).

The importance of appreciation of the al-Quran and the hadith is also emphasized by Hanifah et al. (2017) who stressed that science which is carried out and studied based on the responsibility of humans as khalifah and guided by the al-Quran and the hadith is capable of producing strong-willed human beings, motivated and driven to doing good deeds and always striving to be close to Allah SWT. Mangunjaya (2011) also suggest that environmental conservation based on the al-Quran should include the concepts of existence of humans as conservationist of nature, knowledge about sustainability of nature as a life system, development of responsibility, respect, and caring attitude toward nature, and wisdom in exploitation of natural resources.

In addition, there are four Islamic values related to environmental protection: (1) qana'ah which means being moderate, thrifty and thankful to Allah; (2) mahabbah which means loving and appreciating the environment; (3) ihsan which means making wise choices, refraining from harmful acts toward the environment, and being accountable for one's act; and (4) ta'awun which means teaching one's family to conserve the environment, to reduce the use of natural resources, reduce waste, and participate in campaigns on environmental conservation (Yaacob et al., 2017). In line with that, McKay et al. (2014) believe that better results could be obtained 
by raising awareness of Islamic teachings on the environment rather than making efforts to raise general awareness on conservation issues.

These Islamic values which are related to environmental conservation are also embodied in Malaysia's Environmental Education philosophy, namely: i) conforming to the existence of the environment which is a part of the essential elements of nature where all the contents of this world are subject to God's will, ii) pursuing and refining knowledge that is related to the environment so that we can preserve the environment together, and iii) fostering the spirit of love for the environment by talking about ethical, moral and aesthetic values (Hassan, 2006; Ministry of Education, 1998). Therefore, Islamic values related to environmental conservation need to be applied in TEfEC.

Content investigations of al-Quran verses, the hadith or as-Sunnah, and Islamic values can enhance internal environmental factors and knowledge about the environment. Internal factors include values and attitudes. Attitude is an indicator of the understanding, perception and values which belong to the individual (Efendi et al., 2017). Teaching Islamic values is one of the methods of teaching to know/understand the value of truth, kindness and to cultivate behavioral practices consistently based on the values learned (Efendi et al., 2017). However, the most important value is spiritual value (the belief of attaining long lasting reward and being earnest in worship). Based on Imam Ghazali's views, the process of applying values can be categorized into three main components, namely: i) beliefs, ii) character and akhlak, and iii) action. The beliefs proposed by Imam Al-Ghazali that can be adapted in the context of environmental conservation arethe beliefs that: i) God is the owner of nature; ii) working is considered as ibadah; iii)there needs to be a close relationship between teacher and student; iv) the Prophet s.a.w.is a role model; v)the nature of humans is to obey Allah; vi)the soul is pure; vii)the main sources of reference are the al- Quran and the hadith; and viii) the purpose of life is for the pleasure of Allah (Othman \& Kassim, 2016). Thus, conservation activities would be good deeds (hasanah) in this life and the Hereafter (Efendi, 2017).

Some of the knowledge that human beings must have in conserving the environment are related to environmental sustainability, ecological knowledge and the interpretation of the alQuran and the hadith related to environmental degradation as well as ways to conserve the environment. Appreciation of the interpretation of al-Quran verses can also be observed through the environment in the activity known as tadabbur. Therefore, tadabbur al-Quran in relation to environmental issues is important in TEfEC (Hamzah \& Iksan, 2017; Iksan et al. 2015). Based on Figure 1, knowledge and values related to environmental conservation can therefore enhance attitudes toward environmental conservation behavior.

The combination of values, knowledge and attitudes can develop problem solving skills (Elder, 2003). In problem solving skills, higher order thinking is important in creating awareness of environmental conservation values. Based on the study by Zainoriah (2015), the verses in the al-Quran from surah ar-Rum emphasize that the fundamental element for critical thinking is a synthesis of activities involving listening, observing and contemplating which are carried out in a 


\section{INTERNATIONAL JOURNAL OF ACADEMIC RESEARCH IN PROGRESSIVE EDUCATION AND DEVELOPMENT}

Vol. 8, No. 3, 2019, E-ISSN: 2226-6348 C 2019 HRMARS

serious, focused and deep manner. The key element of critical thinking skills involves the process of information processing. The first level of critical thinking is the importance of having/ providing evidence, explanation or dalil as support for arguments. The second element of higher-order thinking is the readiness and willingness to learn lessons, take heed and caution. These higherorder thinking elements studied by Zainoriah (2015) are in line with Al-Ghazali's elements of higher-order thinking which combine students' cognitive ability with values (Othman \& Kassim, 2016). In this study, these elements of critical thinking skills are reflected in the problem solving skills within the TEfEC conceptual framework.

Responsible environmental behavior can be shown in six aspects, and these are the role of the consumer, ecological management, legislation, political action, persuasion, and education (Hungerford et al., 2005). Thus, the elements in the TEfEC conceptual framework need to be applied in environmental education in order to be to express piety and appreciation of the greatness of God's creation. Overall, TEfEC integration can be summarized in a conceptual framework which is shown in Figure 1. 
INTERNATIONAL JOURNAL OF ACADEMIC RESEARCH IN PROGRESSIVE EDUCATION AND DEVELOPMENT

Vol. 8, No. 3, 2019, E-ISSN: 2226-6348 @ 2019 HRMARS

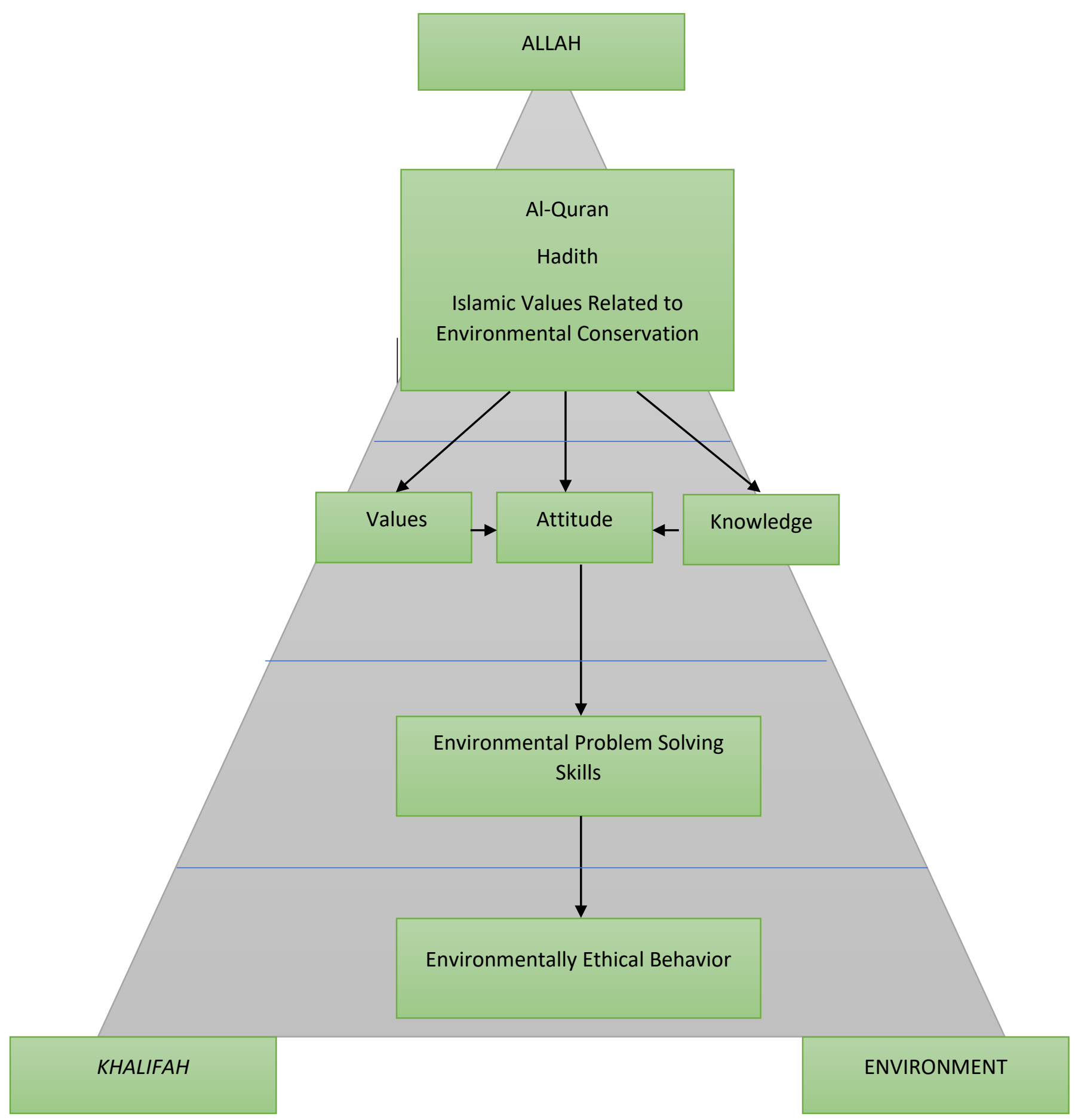

Figure 1 Conceptual Framework of Integrating Tauhidic Elements for Environmental Conservation (TEfEC) 


\section{Conclusion}

This paper has attempted to discuss the development of the conceptual framework of integrating tauhidic elements for environmental conservation (TEFEC) based on literature review. The findings show that Integration of TEfEC can also be applied through three approaches i.e., through teachings from the al-Quran, the hadith and Islamic values that are related to environmental conservation. Environmental value, environmental knowledge, and attitude can enhance by investigation of the content of the al-Quran verses, the hadiths or the as-Sunnah and the Islamic values. It is recommended that future studies investigate the ways in which tauhidic elements can be integrated for environmental conservation using module-based learning in school settings. Science teachers and Islamic teachers should work together in planning TEfEC in teaching and learning so that students can be imbued with ethical Muslim behavior toward the environment in the future and the barriers in environmental education in school settings can be tackled. Moreover, the development of human capital that loves and cares for the environment should not only emphasis on the cognitive aspect but also focus on the development of the Ruh, the Aql, the Qulb, the Nafs and the Jasad. Although this study is a preliminary study, it contributes to existing knowledge in environmental education by providing suggestion of the approaches in integrating TEfEC for environmental education.

\section{Acknowledgement}

This research was funded by GGPM-2018-033, Universiti Kebangsaan Malaysia.

\section{Reference}

Abdul-Matin, I. (2010). Green deen: What Islam teaches about protecting the planet. Berrett Koehler Publishers.

Ahmad, M. Z. (2009). Implementing Environmental Education in Geography Teaching in Secondary Schools: Teacher Knowledge, Attitude, Effectiveness and Practice. Doctor of Philosophy Thesis. Bangi: National University of Malaysia.

Akhter, M., Iqbal, T., \& Khalid, M. (2010). Islamic educational approach to environment protection: a strategic approach for secure and peaceful world. International Journal of Business and Social Science, 1(3), 182-191.

Albab, H. A. U. (2018). Memahami pendidikan agama islam melalui program Adiwiyata (cinta lingkungan) di SMP negeri 2 Lamongan. JALIE; Journal of Applied Linguistics and Islamic Education, 1(2), 254-271.

Hidayat, A. (2015). Pendidikan Islam dan Lingkungan Hidup. Jurnal Pendidikan Islam dan Sains, 4(2), 373-389.

Djainudin, H., \& Sirait, S. (2016). Pembelajaran tauhid berbasis lingkungan Di SMP IT Alam Nurul Islam Yogyakarta. Jurnal Pendidikan Agama Islam, 13(1), 117-131.

Efendi, M. H., Irawati, M. H., Rohman, F., \& Gofur, A. (2017). Islamic view of environmental conservation education in Pondok Pesantren Nurul Haramain Lombok Barat, Indonesia. Journal of Education and Practice, 8(12), 137-140.

Elder, J. L. (2003). A field guide to environmental literacy: Making strategic investments in environmental education. Environmental Education Coalition. 
INTERNATIONAL JOURNAL OF ACADEMIC RESEARCH IN PROGRESSIVE EDUCATION AND DEVELOPMENT

Vol. 8, No. 3, 2019, E-ISSN: 2226-6348 @ 2019 HRMARS

Haddad, M. (2006). An Islamic approach towards environmental education. Canadian Journal of Environmental Education (CJEE), 11(1), 57-73.

Ham, S. H., \& Sewing, D. R. (1988). Barriers to Environmental Education. The Journal of Environmental Education, 19(2), 17-24, DOI: 10.1080/00958964.1988.9942751

Hamzah, N. H. A., \& Iksan, Z. (2017). Pengintegrasian sains tauhidik dalam konsep kitaran air semula jadi melalui pendekatan lesson study. Simposium Pendidikan di Peribadikan: Perspektif Risalah An-Nur (SPRiN2017), 205-214.

Hanifah, S. A., Rahim, F., Iksan, Z. H., Abdullah, W. N. W., Rozi, N., Esa, M. F. M., ... \& Khalid, R. M. (2017). Pengintegrasian Sains Tauhidik: Persepsi Peserta. Ulum Islamiyyah, 21, 43-60.

Hassan, A. (2006). Philosophy of Environmental Education. The Green Era towards Sustainable Generation 4 (3). Malaysia: Department of Environment.

Hungerford, H. R., Bluhm, W. J., Volk, T. L., \& Ramsey, J. M. (2005). The Tbilisi Declaration. Essential Readings in Environmental Education. 3rd Edition. Champaign, Illinois: Stripes Publishing.

Iksan, Z. H., Saper, M. N., \& Rashed, Z. N. (2016). Integration of Tawhidic Science through Lesson Study Approach In Teaching And Learning Science or Islamic Study. Tinta Artikulasi Membina Ummah, 2(1), 40-50.

Iksan, Z., Abdullah, W. N. W., Rambely, A. S., Ahmad, W. J. W., Hazmi, I. R., Hanifah S. A., \& Rahim, F. (2015). Pengintegrasian sains tauhidik dan mentaddabur Al-Quran melalui kem pandang alam. Prosiding International Seminar on Tarbiyah, 455-468.

Kamidin, T., \& Roslan, S. (2014). Pendekatan ekopsikologi dalam pelaksanaan pendidikan alam sekitar. Serdang: Universiti Putra Malaysia Press.

Fua, L. J., Nurlila, R. U., Gunawan, F., \& Wekke, I. S. (2018, May). Islamic Education on Formation of Environmental Awareness in Pondok Pesantren Indonesia. In IOP Conference Series: Earth and Environmental Science (Vol. 156, No. 1, p. 012035). IOP Publishing.

Lewis, H. (2007). Excellence without a soul: Does liberal education have a future?. Public Affairs.

Mangunjaya, F. M. (2011). Developing environmental awareness and conservation through Islamic teaching. Journal of Islamic Studies, 22(1), 36-49.

Mănoiu, V. M., Arslan, R., Madani, A., \& Düzgüneş, E. (2016). Environmental education in the Holy Quran. Lucrările Seminarului Geografic" Dimitrie Cantemir", 42, 157-164.

McKay, J. E., Mangunjaya, F. M., Dinata, Y., Harrop, S. R., \& Khalid, F. (2014). Practise what you preach: a faith-based approach to conservation in Indonesia. Oryx 48(1), 23-29.

Ministry of Education. (1998). Buku panduan guru: Pendidikan Alam Sekitar merentas kurikulum KBSR. Kuala Lumpur: Pusat Perkembangan Kurikulum Kementerian Pendidikan Malaysia.

Mustam, B., \& Daniel, E. S. (2018). Informal and Formal Environmental Education Infusion: Actions of Malaysian Teachers and Parents among Students in a Polluted Area. MOJES: Malaysian Online Journal of Educational Sciences, 4(1), 9-20.

Othman, M. S. B., \& Kassim, A. Y. B. (2016). Elemen kemahiran berfikir aras tinggi (KBAT) di dalam amalan pengajaran guru Pendidikan Islam menurut Imam Ghazali. Jurnal Sultan Alauddin Sulaiman Shah, 3(2), 80-91.

Rahim, F. (2017). Pemerkasaan Ulul Albab Melalui Modul STEM Bersepadu STEMind. O-JIE: Online Journal of Islamic Education, 3, 1-12. 
INTERNATIONAL JOURNAL OF ACADEMIC RESEARCH IN PROGRESSIVE EDUCATION AND DEVELOPMENT

Vol. 8, No. 3, 2019, E-ISSN: 2226-6348 @ 2019 HRMARS

Rahman, H. A. (2016). Penyelesaian krisis alam sekitar: mengapa islam? Seminar Serantau Pengurusan Persekitaran. Retrieved 5 December 2017, from: https://www.researchgate.net/profile/Haliza_Abdul_Rahman2/publication/309856207 _Penyelesaian_Krisis_Alam_Sekitar_Mengapa_Islam/links/58255a2208ae7ea5be780c4 $\mathrm{f} /$ Penyelesaian-Krisis-Alam-Sekitar-Mengapa-Islam

Rahman, H. A. (2018). Usaha dan cabaran dalam mengaplikasikan pendidikan alam sekitar dalam sistem persekolahan di malaysia. Asian Journal of Environment, History and Heritage, 1(2), 61-70

Ramli, A. (2003). Development of Self-Learning Modules for Environmental Education for Secondary School Students. Bachelor of Education (Engineering and Vocational) Thesis. Faculty of Engineering Technology. Kolej Universiti Teknologi Tun Hussein Onn .

Rusdi, M. (2010). Pemeliharaan dan pemuliharaan alam sekitar menurut perspektif al-Quran Penerbit Universiti Tun Hussein Onn Malaysia.

Sakka, A., Bulu, D. G., \& Lullulangi, M. (2016). Development of an environmental education learning model for vocational high schools. International Journal of Applied Environmental Sciences, 11(2), 647-656.

Salehudin, M., Nusaibah, S., \& Iksan, Z. H. (2017). Integration of Tauhid (Faith) Element in Biology Education. Journal of Educational Sciences, 1(1), 11-23.

Savita, K. S, Zainuddin, N. A., Muniandy, M., \& Mehat, M. (2017). A mobile based application on environmental education for primary school children. Journal of Theoretical and Applied Information Technology, 95(22), 6300-6314.

Tamuri, A. H. (2015). Educating teacher for muallaf: the tawhidic base. Jurnal Hadhari: An International Journal, 7(2), 1-10.

Yaacob, M., Nasir, Z. M., Petera, W. S. H. W., Basri, H., Ibrahim, I. A., Othman, M. Y., \& Mokhtar, M. (2017). Transformation of Muslim Behaviour towards Sustainable Environment: Perspectives of Non-Governmental Organisations in Klang Valley Akademika, 87(2), 1930.

Zainoriah, K. (2015). Elements of Critical Thinking Based on Quranic Perspective: A Study of ArRum. Doctor of Philosophy Thesis. Department of Islamic Faith and Thought. Academy of Islamic Studies. University of Malaya. 